\title{
Topic Study Group No. 53: Philosophy of Mathematics Education
}

\author{
Paul Ernest, Ladislav Kvasz, Maria Bicudo, Regina Möller \\ and Ole Skovsmose
}

What is the philosophy of mathematics education? It can be an explicit position that is formulated, reformulated, criticized, refined, etc. But it can also refer to implicit assumptions and priorities, including paradigmatic assumptions that one need not be aware of, but which might be identified through, let us call it, a philosophical archaeology.

The philosophy of any activity comprises its aims or rationale. Thus we ask: what is the purpose of teaching and learning mathematics? An answer explains why we engage in these practices and what we hope will be achieved. But just considering such purposes quickly leads to seeing the divergence in aims and values of different groups.

A broader view of the philosophy to mathematics education looks at the applications of topics such as epistemology, philosophy of mathematics, ethics and aesthetics. It applies philosophical methods to a critical examination of the assumptions, reasoning and conclusions of mathematics education, systematically enquiring into fundamental questions:

- What is mathematics?

- How does mathematics relate to society?

- Why teach mathematics?

- What is the nature of learning (mathematics)?

Co-chairs: Paul Ernest, Ladislav Kvasz.

Team members: Maria Bicudo, Regina Möller, Ole Skovsmose.

P. Ernest $(\square)$

University of Exeter, Exeter, UK

e-mail: p.ernest@ex.ac.uk

L. Kvasz

Charles University Prague, Prague, Czech Republic

e-mail: ladislavkvasz@gmail.com

(C) The Author(s) 2017

G. Kaiser (ed.), Proceedings of the 13th International Congress on Mathematical

Education, ICME-13 Monographs, DOI 10.1007/978-3-319-62597-3_80 
- What is the nature of mathematics teaching?

- What is the significance of information and communication technology in the teaching and learning of mathematics?

- What is the status of mathematics education as knowledge field?

The philosophy of mathematics education matters because it gives people new 'glasses' through which to see the world. It enables people to see beyond official stories about the society, mathematics, and education. It provides thinking tools for questioning the status quo, for seeing 'what is' is not what 'has to be'; enabling us to imagine alternatives possibilities. A preconference overview of the field was published: Ernest et al. (2016), available free from Springer Open.

At the conference, itself the sessions included expert presentations on key questions and issues of the field and was time made available for questions, discussion and participation.

The Tuesday session began with a welcome and an introduction from Paul Ernest and Ladislav Kvasz. Chaired by Ladislav Kvasz and Ole Skovsmose two main presentations were given:

Paul Ernest An overview philosophy of mathematics education.

Due to personal circumstances the second speaker was unable to attend so the second presentation was:

Paul Ernest The collateral damage of learning mathematics.

The Wednesday session was chaired by Paul Ernest and Ladislav Kvasz and consisted of two presentations:

Ole Skovsmose The politics of meaning in mathematics education

Maria Bicudo Developments in philosophy in/of mathematical education: ontological questions posed by the presence of computers etc.

On the Friday, there were two parallel sessions chaired by Paul Ernest and Ladislav Kvasz. The presentations were as follows:

Jeff Evans and Keiko Yasukawa Researchers as policy actors? examining the interaction between mathematics education research and PIAAC

Jörn Schnieder and Ingrid

Scharlau

Iskra Nunez

Uwe Schürmann

Nadia Stoyanova Kennedy

Michael Meyer
Reading mathematical texts with philosophical methods.

Theoretical incompleteness and mathematics education.

the order of the discourse on modelling.

Opening a philosophical space in the mathematics curriculum.

Concept formation as a rule-based use of words. 
Cintia Aparecida Bento Santos \& Possibilities of the phenomenological approach Fernanda Aparecida Ferreira

Filipe Santos Fernandes and of philosophical hermeneutics in type search state of art.

History of scientific and academic production in mathematics education-representation, institution and policy.

On Saturday, the session was chaired by Paul Ernest and Maria Bicudo, and the following talks were given.

Ladislav Kvasz The language of mathematics in a historical, epistemological, and educational perspective.

Regina Möller The teaching of velocity in mathematics classes-chances for philosophical ideas.

There was a closing panel discussion with the main presenters Paul Ernest, Ladislav Kvasz, Maria Bicudo, Regina Möller, Ole Skovsmose and the audience. Lastly, the publication strategy of the group was discussed, with two elements. First, there is the publication of all papers presented at TSG 53 including poster presentations, in Philosophy of Mathematics Education Journal (2016) number 31, a special issue dedicated to TSG 53 papers. Second, the publication of the best papers rewritten and expanded, plus invited outside expert contributions in a special monograph (Ernest, forthcoming).

\section{References}

Ernest, P. (Ed.). (forthcoming). The philosophy of mathematics education today. Switzerland: Springer.

Ernest, P., Skovsmose, O., Van Bendegem, J. P., Bicudo, M., Miarka, R., Kvasz, L., et al. (2016). The philosophy of mathematics education, ICME-13 surveys. Switzerland: Springer Open. Consulted on 23/01/2017 via URL http://link.springer.com/book/10.1007\%2F978-3-31940569-8

(2016) The Philosophy of Mathematics Education Journal, 31 (November 2016) Special issueThe philosophy of mathematics education at ICME 13. Consulted on 23/01/2017 via URL http://socialsciences.exeter.ac.uk/education/research/centres/stem/publications/pmej/pome31/ index.html

Open Access Except where otherwise noted, this chapter is licensed under a Creative Commons Attribution 4.0 International License. To view a copy of this license, visit http://creativecommons. org/licenses/by/4.0/.

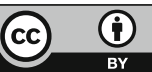

